\title{
Anabases
}

ANABASES Traditions et réceptions de l'Antiquité

11 | 2010

Varia

\section{Jean-Philippe GENET (dir.), Rome et l'État moderne européen}

\section{Philippe Foro}

\section{OpenEdition}

\section{Journals}

Édition électronique

URL : http://journals.openedition.org/anabases/919

DOI : 10.4000/anabases.919

ISSN : 2256-9421

\section{Éditeur}

E.R.A.S.M.E.

\section{Édition imprimée}

Date de publication : 1 mars 2010

Pagination : 288

ISSN : 1774-4296

\section{Référence électronique}

Philippe Foro, « Jean-Philippe genet (dir.), Rome et l'État moderne européen », Anabases [En ligne], 11

2010, mis en ligne le 01 septembre 2011, consulté le 22 septembre 2020. URL : http://

journals.openedition.org/anabases/919; DOI : https://doi.org/10.4000/anabases.919

Ce document a été généré automatiquement le 22 septembre 2020.

(c) Anabases 


\title{
Jean-Philippe GENET (dir.), Rome et l'État moderne européen
}

\author{
Philippe Foro
}

\section{RÉFÉRENCE}

Jean-Philippe GENET (dir.), Rome et l'État moderne européen, Rome, École française de Rome, 2007, $444 \mathrm{p}$.

49 euros / ISBN 978-2-7283-0771-5.

1 Cet ouvrage rassemble les seize contributions du colloque réuni à l'École Française de Rome le 31 janvier et les $1^{\text {er }}$ et 2 février 2002 autour du thème de «Rome et l'État moderne en Europe ", titre d'ailleurs quelque peu trompeur car l'époque moderne n'est guère présente (une seule contribution à côté de cinq contributions sur la Rome antique, sept contributions sur l'époque médiévale et une contribution introductive de Jean-Philippe Genet). Ayant noté que «la conscience d'une perte, d'un manque, et à partir de là l'image d'un modèle, voire le sentiment d'une autorité (paternelle dirons certains) perdue, n'ont jamais cessé de hanter la conscience des hommes du Moyen Âge » (p.4), les participants du colloque ont souhaité analysé les influences romaines dans la constitution de l'État post-Empire romain en une série de va-et-vient comparatifs entre la période antique et l'époque romaine. Une série de thèmes se détachent de ces études.

Tout d'abord, le temps. L'Antiquité tardive chrétienne a légué un temps liturgique qui a lui-même christianisé le temps profane même si Patrice Boudet et Olivier Guyotjeannin remarquent qu'encore au début $\mathrm{du}_{\mathrm{XIII}}^{\mathrm{e}}$ siècle, les notaires du pape Innocent III ont du mal avec le calendrier chrétien. Pour leur part, les puissances laïques se sont appropriées la maîtrise du temps avec, par exemple, une des premières horloges de palais dans la Sicile de Roger II en 1142 ou les Grandes Chroniques de France sous Charles V. Vient ensuite le rôle capital de l'écrit. Après que Claude Moatti a présenté la communication écrite à Rome sous la République et le Haut-Empire, Richard Britnell et 
Isabella Lazzarini ont analysé la communication écrite en Europe du nord et en Europe méridionale, des registres administratifs suédois et norvégiens du xiII siècle aux cartulaires chroniques de l'ère méditerranéenne. La question de l'écrit conduit à l'étude du droit, d'abord à Rome avec Jean-Michel David à propos de la sanction pénale et Yann Rivière sur l'appareil judiciaire de l'Antiquité tardive romaine, pour aboutir à la justice française de la fin du Moyen Âge avec Claude Gauvard. Enfin, le livre aborde la représentation symbolique du pouvoir qu'il soit iconographique avec la contribution de Michel Sot sur l'iconographie impériale sous les Carolingiens ou celle de Jean-Philippe Genet sur la légitimation religieuse du pouvoir dans l'Europe médiévale latine au travers du sacre ou des pouvoirs thaumaturges des rois de France.

3 L'immense sujet abordé par ce colloque donne l'occasion d'offrir au lecteur un ensemble riche permettant souvent une comparaison entre les périodes antique et médiévale. Aussi peut-on juste regretter que la période moderne des $\mathrm{XVI}^{\mathrm{e}}$-XVIII ${ }^{\mathrm{e}}$ siècles ait été laissée de côté. Mais la qualité appelle souvent des désirs de complément.

\section{AUTEURS}

\section{PHILIPPE FORO}

Université de Toulouse (UTM)

philippe.foro@wanadoo.fr 